
May 1936

\title{
EFFECTS OF PARTIAL PREHYDRATION AND DIFFERENT CURING TEMPERATURES ON SOME OF THE PROPER- TIES OF CEMENT AND CONCRETE
}

\author{
By F. B. Hornibrook, G. L. Kalousek, and C. H. Jumper
}

\section{ABSTRACT}

Data presented were obtained in studies of three types of commercial cements, including two low-heat Boulder Dam, two high-early-strength, and six standard portland cements. Portions of each of the cements of the latter two types were steam prehydrated so that the ignition losses were increased for each cement to approximately 3 and 5 percent, respectively. The heats of hydration and also the compressive strengths of concrete specimens made of the untreated and of the prehydrated cements were determined for the ages of $7,28,90$ days, and 1 year. Three curing conditions were used; continuous storage at $70^{\circ} \mathrm{F}$, continuous storage at $150^{\circ} \mathrm{F}$, and three respective combinations of storage at 70 and $150^{\circ} \mathrm{F}$. Chemical analyses, calculated compound compositions, and specific surfaces are given. The heats of hydration and compressive strengths were both reduced by prehydration of the cements, the 5 percent prehydration causing greater reductions than the 3-percent. At the later ages the heats of hydration obtained at continuous $150^{\circ} \mathrm{F}$ curing were lower than the heats obtained at continuous $70^{\circ} \mathrm{F}$ curing. The strengths at later ages, however, were not greatly affected by the curing temperature. The 5-percent prehydrates of standard portland cements had heats of hydration that would pass the lowheat specifications for Boulder Dam cements. The expansion results on specimens made of the untreated and of the prehydrated cements stored in sodium sulfate solutions show that with the exception of the cements high in tricalcium aluminate the prehydrations increase the resistance to the action of sodium sulfate. The 5-percent prehydrates had greater resistance to the sulfate action than the 3-percent.

\section{CONTENTS}

I. Introduction

II. Description of cements_._.

1. Types of cements used

2. Chemical analysis and fineness

3. Prehydration

III. Preparation and testing of specimens

1. Heat of hydration tests

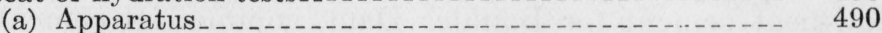

(b) Preparation and storage of sample $\ldots \ldots \ldots \ldots 1$

(c) Testing of samples _... 491

2. Strength tests

(a) Description of test specimens............... 491

(b) Mixing and storage

3. Expansion tests_..._.

(a) Plastic-mortar specimens_-variable storage_....... 492

(b) Variable mixes - constant storage _.......... 492 
IV. Heat of hydration results

1. Effect of partial prehydration on the heat of hydration...

(a) Heats of hydration of cements and prehydrates......

(b) Reduction in heat of hydration per percent increase in loss on ignition

(c) Comparison of prehydrated cements with Boulder Dam cements . .

(d) Calculation of the heats of hydration

2. Effects of curing temperature on heats of hydration......

(a) Continuous storage at 70 and $150^{\circ} \mathrm{F} \ldots \ldots$

(b) Combined storage

(c) Study of differences in heat evolution at high and low

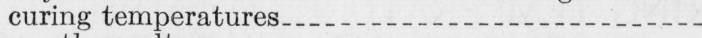

V. Compressive-strength results

1. Effect of prehydration on the compressive strength of concrete

2. Effect of combined storage on strength

3. Comparison of untreated and of prehydrated cements with Boulder Dam cements.........

VI. Comparison of heat and strength results

1. Continuous storage at 70 and $150^{\circ} \mathrm{F}$
2 . Heats and strengths for combined storage VII. Expansion results

1. Constant mix, variable storage

(a) Expansion in water storage

(b) Storage in a 2-percent sodium sulfate solution ......

(c) Storage in a 10-percent sodium sulfate solution .....

2. Accelerated sodium sulfate tests

3. Sulfate resistance according to the Merriman test method.-

\section{INTRODUCTION}

General recognition has been given the importance of preventing the development of excessive temperatures within large masses of concrete caused by the heat evolved from the hydrating cement. Some of the cracking that has occurred in mass concrete undoubtedly has been caused by the expansion and contraction accompanying the excessive rise and fall of temperatures. These large temperature changes may be restricted by removing the heat with an integral cooling system, or by the use of "low-heat" cements.

The numerous studies that have been made on methods of producing low-heat cements have centered chiefly on the effects of chemical and compound composition and fineness of grinding on the heat of hydration. Scattered findings of several investigators have indicated that another method of producing a low-heat cement might be that of partially hydrating standard portland cements prior to use.

In a preliminary survey made at this Bureau of possible sources of low-heat cement for Boulder Dam, commercial cements which had been partially prehydrated were studied [1]. ${ }^{1}$ It was found that neat-cement pastes made with prehydrated cements evolved less heat up to 24 hours than pastes made from the corresponding untreated cements. S. L. Meyers [2] found that prehydration of a cement with increasing amounts of water retarded the heat evolution in increasing amounts for the first 3 days of hydration; for an addition of 3.58 percent of water the 3- and 7-day strengths were also consider-

${ }_{1}$ The numbers in brackets here and elsewhere in the text refer to the numbered references at the end of the paper. 
ably reduced. Woods and co-workers [3], and also Davis and coworkers [4], found that cements aged in the laboratory so the loss on ignition was appreciably increased had reduced heats of hydration.

In order to obtain more comprehensive data on the effect of partial prehydration on the several properties of cement, the Bureau undertook the study of two types of cement that were prehydrated with steam at atmospheric pressure so that the total ignition loss was increased in each case to approximately 3 and 5 percent. These cements, before and after partial prehydration, are compared with Boulder Dam low-heat cements.

\section{DESCRIPTION OF CEMENTS}

\section{TYPES OF CEMENTS USED}

Three types of portland cements, consisting of 10 different commercial brands, were used in this investigation. Two of the group were high-early-strength, six were standard, and two were Boulder Dam low-heat portland cements. The low-heat cements were composites of a number of samples of Boulder Dam cements passing Bureau of Reclamation specification 591-D. Portions of two highearly-strength and six standard portland cements were prehydrated to have approximately 3 and 5 percent loss on ignition, respectively.

\section{CHEMICAL ANALYSIS AND FINENESS}

Complete chemical analyses and determinations of specific surface were made of all cements; ${ }^{2}$ the results are presented in table 1 . The specific surfaces, expressed in square centimeters per gram of cement, were determined with the Wagner turbidimeter [5].

TABLE 1.-Chemical analyses and calculated compound compositions of the cements

\begin{tabular}{|c|c|c|c|c|c|c|c|c|c|c|c|c|c|c|c|c|c|c|c|c|}
\hline \multirow{3}{*}{$\begin{array}{c}\mathrm{Ce}- \\
\text { ment }\end{array}$} & \multicolumn{9}{|c|}{ Chemical composition } & \multicolumn{11}{|c|}{ Compound composition } \\
\hline & \multirow[b]{2}{*}{ 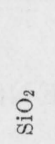 } & \multirow[b]{2}{*}{$\begin{array}{l}0_{\infty}^{\infty} \\
0 \\
0\end{array}$} & \multirow[b]{2}{*}{$\begin{array}{l}0 \\
\text { ర్షే }\end{array}$} & \multirow[b]{2}{*}{$\begin{array}{l}0 \\
0 \\
0\end{array}$} & \multirow[b]{2}{*}{$\begin{array}{l}0 \\
0_{0} \\
\sum_{4}^{1}\end{array}$} & \multirow[b]{2}{*}{ 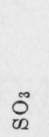 } & \multirow{2}{*}{ 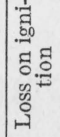 } & \multirow{2}{*}{ 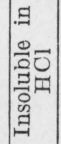 } & \multirow{2}{*}{ 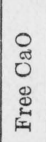 } & \multicolumn{4}{|c|}{ Bogue 1} & \multicolumn{3}{|c|}{$A^{2}$} & \multicolumn{4}{|c|}{$\mathrm{B}^{3}$} \\
\hline & & & & & & & & & & 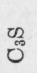 & $\stackrel{\infty}{0}$ & ర্ & 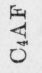 & $\begin{array}{l}0 \\
0 \\
0\end{array}$ & $\begin{array}{l}\text { Tू } \\
\text { ర్ల }\end{array}$ & 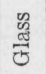 & $\begin{array}{l}\text { कू } \\
0 \\
0\end{array}$ & ర్లి & $\begin{array}{l}4 \\
0 \\
0\end{array}$ & 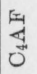 \\
\hline & & 2.4 & 3.7 & & & 1. 6 & 1.0 & 0.1 & 0.2 & 27 & & 6 & 7 & 27 & 52 & 16 & 27 & 55 & 6 & \\
\hline & & 5. & & 58 & & & 1. 3 & .2 & $(5)$ & 14 & & 5 & 17 & 8 & & 8 & 14 & 6 & 5 & 17 \\
\hline & & 6. & & & & & & .1 & .6 & 5 & & 3 & 18 & 42 & & & & & 3 & 18 \\
\hline & & 3. & & 62. & & & & .3 & & 46 & & 9 & 9 & & & & & & 8 & 9 \\
\hline & 19. & 2. & 7. & 64. & 3. & 1. & 1. & .2 & . & 5 & 19 & 16 & 7 & 57 & 8 & & 57 & 13 & 10 & 7 \\
\hline & 20. & 42. & & & & & & .2 & & 5 & 2 & 12 & 7 & 54 & 14 & & 6 & 18 & 8 & 7 \\
\hline & & 3. & & & & & & .3 & & & & 12 & 9 & 52 & & & & 20 & 10 & 9 \\
\hline & 21 . & 2 . & 5. & 65. & 2. & 1. & 1. & .5 & & 52 & 23 & 11 & 7 & 56 & 15 & & 56 & 20 & 7 & 7 \\
\hline & 18. & 2. & 7. & 64. & & 2. & 1. & .2 & 1. 2 & 56 & 11 & 14 & 18 & 62 & 1 & 26 & 62 & 6 & 9 & 8 \\
\hline & 21.3 & 3.4 & & 61.2 & & 2.9 & 1.8 & & & 39 & 31 & 8 & 11 & 39 & 27 & 23 & 39 & 31 & 8 & 11 \\
\hline
\end{tabular}

1 Compounds calculated according to method of Bogue.

2 Compounds calculated according to method of Lea; "liquid forms a glass."

3 Compounds calculated according to method of Lea; "crystallizes independently at $1,400^{\circ}$ C."

4 Contains $0.5 \%$ of ferrous iron.

$\checkmark$ Trace.

\section{PREHYDRATION}

The partial hydration of the cements was obtained by exposing each cement to an atmosphere of steam in a rotating oven maintained ${ }^{2}$ The chemical analyses were made by E. P. Flint, and the determinations of specific surface were made
by R. L. Blaine, both of this Bureau. 
at about $100^{\circ} \mathrm{C}$ by means of electrical heaters. The charge in the oven was first brought to a temperature of $100^{\circ} \mathrm{C}$, then the steam, which was generated in a flask at atmospheric pressure, was passed into the oven. Because of the heat losses through the walls of the oven, the temperature in the region near the walls was below $100^{\circ} \mathrm{C}$. Under these conditions it was possible to prehydrate a cement in approximately 3 hours. There was some caking of the cements on the walls of the oven, but the product obtained was easily broken up. The charge, after removal from the oven, was crushed and passed through a 20 -mesh sieve, then ground in a ball mill to the approximate fineness of the original cement. The loss on ignition was determined by the standard method.

What actually takes place during the steam hydration is not definitely known. Bied [6] found that steam treatment of "entirely silicious cements" above $100^{\circ} \mathrm{C}$ did not cause them to absorb water. "Artificial cements" and "quick-setting cements", however, did absorb water at $110^{\circ} \mathrm{C}$. Kline and Phillips [7] found that the individual compounds of cement, when exposed to steam, hydrated at different rates. Tricalcium aluminate, at $100^{\circ} \mathrm{C}$ and lower temperatures, hydrated much more rapidly than tricalcium silicate, while dicalcium silicate showed no appreciable hydration for the given exposures up to 4 hours. These compounds in the pure crystalline form as studied by Kline and Phillips undoubtedly behave differently than when in a heterogeneous mixture such as cement, especially since in the cement some of the alumina may be in the glass phase [8].

Throughout this paper the two series of prehydrated cements are referred to as the 3- or 5-percent prehydrates. This designation refers to the total loss on ignition of the respective series and not to the amount of water added by the steam treatment. Inasmuch as the original ignition losses of the cements ranged from 0.9 to 1.8 percent, the actual amounts added by the prehydration treatment were correspondingly less than indicated by the 3- and 5-percent designations. No attempt was made to determine what part of the total water was actually combined chemically and what part was so-called "free water."

\section{PREPARATION AND TESTING OF SPECIMENS}

\section{HEAT OF HYDRATION TESTS}

The results for heat of hydration were obtained by the heat of solution method [3]. The value for the heat of solution of the test specimen, subtracted from the value for the heat of solution of the original sample (cement or prehydrate), gave the heat of hydration.

The results are expressed on the basis of calories per gram of the original sample of cement or prehydrate (not on the ignited weight basis).

(a) APPARATUS

The calorimeter in which the heats of solution were determined is identical with that developed by the Bureau for the routine testing of the cements used in the construction of Boulder Dam. ${ }^{3}$ The details

${ }^{3}$ The Bureau calorimeter is a refinement of the general type developed by Woods and co-workers [3], that developed at the University of California [9], and that described by Stenzel and Morris [10]. 
of construction and operation of the calorimeter are described in U. S. Bureau of Reclamation specification 566 for Boulder Dam cement.

In brief, the calorimeter consists of an outer vessel with exit chimneys in the lid, an inner or reaction vessel, a cylindrical heating unit which also acts as a stirring tube, and a bakelite valve for introducing the cement charge. All metallic surfaces within the calorimeter exposed to acid are coated with acid-resistant enamel. A stirrer of clear bakelite propelled by a synchronous motor provides the stirring. The temperature rise is measured with a $25-\mathrm{ohm}$ platinum resistance thermometer, encased in a platinum sheath, in conjunction with a Mueller temperature bridge. The acid charge for dissolving the cement sample is a mixture of $10.0 \mathrm{ml}$ of $\mathrm{cp}$ hydrofluoric acid $(48 \%)$ and $648.5 \mathrm{~g}$ of $2.500 \pm .002$ normal nitric acid. During a determination of heat of solution the calorimeter is immersed in a water bath which is maintained at $25.000 \pm .005^{\circ} \mathrm{C}$ by automatic control. Calibration of the calorimeter and contents is effected by passing a measured amount of electric current through the heating coil of known resistance, and measuring the resultant temperature rise. The heat-capacity determinations were made in duplicate at frequent intervals, the precision of the apparatus being such that the duplicates checked within 0.1 percent.

\section{(b) PREPARATION AND STORAGE OF SAMPLE}

A smooth cement paste was prepared by intimately mixing the cement and water in a ratio of 1:0.53, by weight. The required number of glass specimen vials were filled and stoppered with corks. The vials to be stored continuously at $70^{\circ} \mathrm{F}$ were further sealed with paraffin; all other vials were sealed with a high-melting bituminous material. All specimens were stored at $70^{\circ} \mathrm{F}$ for the first 24 hours. One series of specimens, hereinafter designated as the constant $70^{\circ} \mathrm{F}$ storage series, remained at that temperature until tested. Another series, designated as the constant $150^{\circ} \mathrm{F}$ storage series, was removed from the $70^{\circ} \mathrm{F}$ storage after the initial 24 -hour period and stored at $150^{\circ} \mathrm{F}$ until tested. A third series, designated as combined storage series, after the initial 24 hours at $70^{\circ} \mathrm{F}$, was placed in $150^{\circ} \mathrm{F}$ storage, then at the total elapsed time of 7,28 , and 90 days, the specimens were returned to the $70^{\circ} \mathrm{F}$ storage to be tested at the age of 1 year.

\section{(c) TESTING OF SAMPLES}

At the designated time of test the hardened specimen was freed from the glass of the vial and quickly ground in a mortar to such a fineness that no residue was left on the no. 30 sieve. The calorimeter charge was immediately weighed and its heat of solution determined. The latter was calculated as calories per gram of cement (or prehydrate) being tested.

\section{STRENGTH TESTS}

\section{(a) DESCRIPTION OF TEST SPECIMENS}

The compressive-strength specimens were made of prehydrated or untreated cements, Potomac River sand, and Potomac River gravel. The tests were made on $3-$ by 6 -in. cylinders made from a 1:2:4 mix by volume, and a constant cement-water $(\mathrm{C} / \mathrm{W})$ ratio of 1.45. Gravel was taken in the proportions of 1 part of $1 / 4$ to $3 / 8$ in. to $1 \frac{1}{4}$ parts of $3 / 8$ to $3 / 4$ in.

\section{(b) MIXING AND STORAGE}

Dry materials sufficient for 12 specimens were mixed thoroughly in a shallow pan, then the water was added and the mixing continued for $2 \frac{1}{2}$ minutes. All operations were performed in a constant-temperature room at $70 \pm 2^{\circ} \mathrm{F}$. The specimens were fabricated in $3-$ by 6 -in. tin-plated cylindrical cans. The cans were filled one-third full and the contents rodded with a bullet-pointed steel rod $1 / 2$ in. in 
diameter, and the same procedure was repeated for the two succeeding layers.

The molded specimens were cured at $70^{\circ} \mathrm{F}$ for 24 hours. At this age the cans were sealed with a bituminous material that was capable of withstanding a temperature of $170^{\circ} \mathrm{F}$ without flowing. Immediately after sealing, 12 specimens for each cement were stored at $70^{\circ} \mathrm{F}$, and 21 specimens were stored at $150^{\circ} \mathrm{F}$.

Three specimens from each storage were tested in compression at 7,28 , and 90 days, and 1 year. Also, 3 specimens from the $150^{\circ} \mathrm{F}$ storage were removed at 7,28 , and 90 days and placed in the $70^{\circ} \mathrm{F}$ storage; at a total age of 1 year they were tested in compression.

\section{EXPANSION TESTS}

Two types of expansion specimens were used in the study of linear changes of mortars stored in water and aqueous solutions of sodium sulfate.

(a) PLASTIC-MORTAR SPECIMENS-VARIABLE STORAGE

The first type of specimen was a bar 1 by 1 by 11 inches made from a 1:2.75 mix, by weight, of cement and pit-run Ottawa sand, using a $\mathrm{C} / \mathrm{W}$ ratio of 1.88 by weight. The bars cast in molds contained glass plugs of $3 / 16$ in. diameter by $1 / 2$ in. long, placed in the center of each end, and protruding $1 / 8$ in. beyond the end of the bar.

The bars, after 24 hours of curing in the molds at $70^{\circ} \mathrm{F}$, were removed and placed in tap water at the same temperature. A set of 3 bars for each cement was cured in water for 7 days and then totally immersed in a 2-percent (anhydrous basis) aqueous solution of sodium sulfate. A second set of 3 bars was cured in water for 90 days and then immersed in a 10-percent solution of sodium sulfate. A third set of 3 bars was kept immersed in water for all ages of test.

Measurements of change of length were made with an Ames dial graduated to 0.0001 in. The dial was mounted rigidly in a steel frame. An invar-steel bar was used for the standard reference length. Measurements were made at 1, 2, 3, and 4 weeks, then every fourth week thereafter. The results are reported as percentage linear change based on the length of bar when put under test.

(b) VARIABLE MIXES-CONSTANT STORAGE

The second type of specimen, designed to be used in an accelerated test, was a bar 1 by 1 by 6 in., with two parallel faces indented with a triangular form ${ }^{4}$ to increase the total area. Three mixes, 1:3, 1:4, and 1:5 parts of cement to parts of standard Ottawa sand, by weight, were used. The amount of mixing water was determined from the normal consistency according to Feret's relationship:

$$
Y=2 / 3 \frac{P}{n+1}+K
$$

where $Y=$ percentage of water for mortar, $P=$ percentage of water for normal consistency, $n=$ parts of sand for 1 part of cement, and $K=\mathrm{a}$ constant (6.5 for standard Ottawa sand). The bars after molding were cured in a damp closet (100 percent humidity) at $70 \pm 2^{\circ} \mathrm{F}$ for 24 hours, then removed from the molds, and cured in tap water at

\footnotetext{
4 In casting the bars, there was placed in the center of the mold bottom a 3/-in., $90^{\circ}$ angle of brass equal to the length of the specimen. A similar angle was inserted likewise in the top of the filled mold, placed so that the ends of the angle legs were in the plane of the surface of the bar.
} 

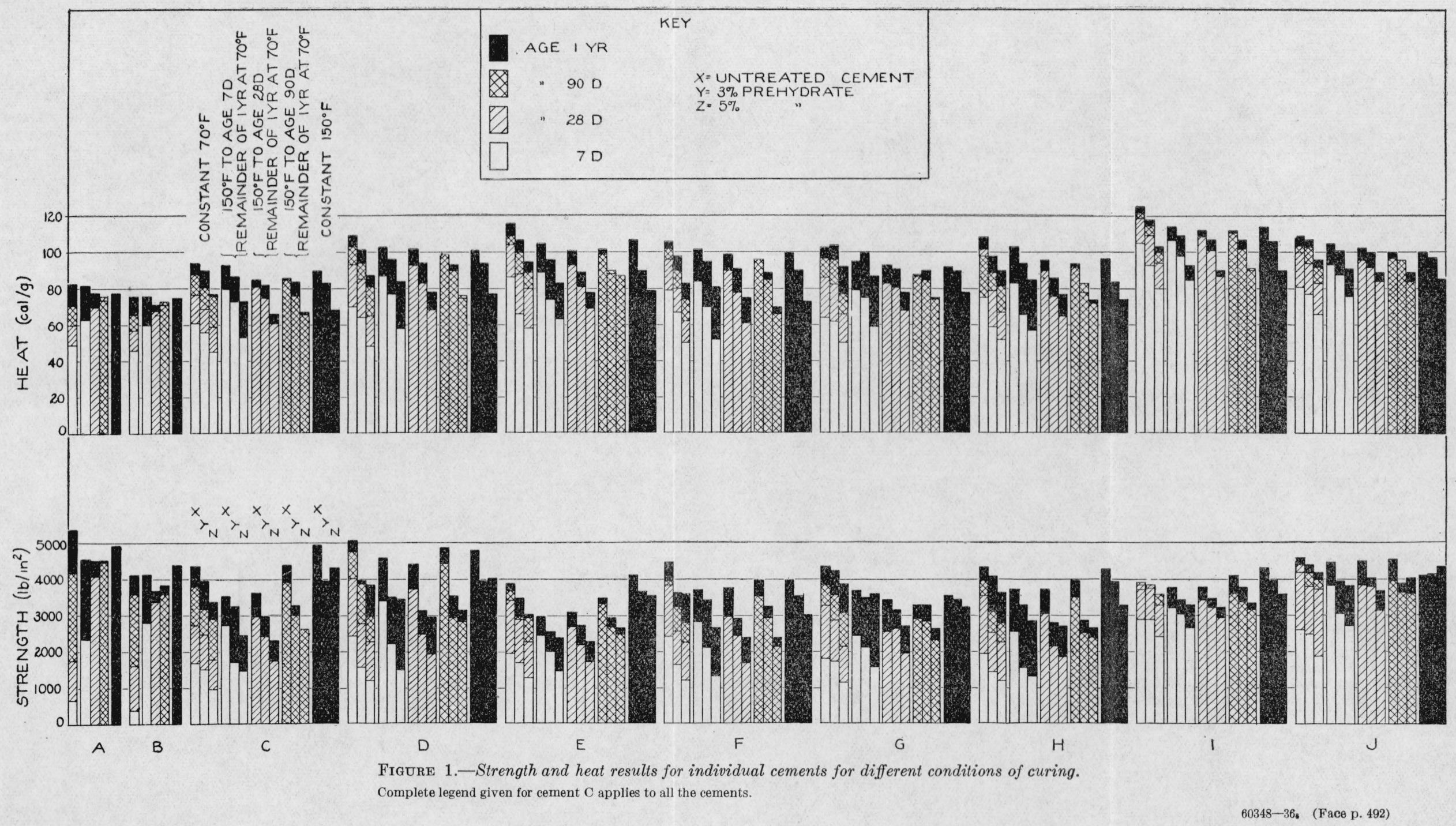
the same temperature for 48 hours. At this age (3 days) the bars were measured for length and placed in a 10-percent aqueous solution of sodium sulfate maintained at $70 \pm 2^{\circ} \mathrm{F}$. Length changes were determined each week, and are expressed as percentage linear change based on the length of the bars at 3 days.

\section{HEAT OF HYDRATION RESULTS}

\section{EFFECT OF PARTIAL PREHYDRATION ON THE HEAT OF HYDRATION}

(a) HEATS OF HYDRATION OF CEMENTS AND PREHYDRATES

The heats of hydration of the individual cements and the corresponding partial prehydrates, together with the average heats of the

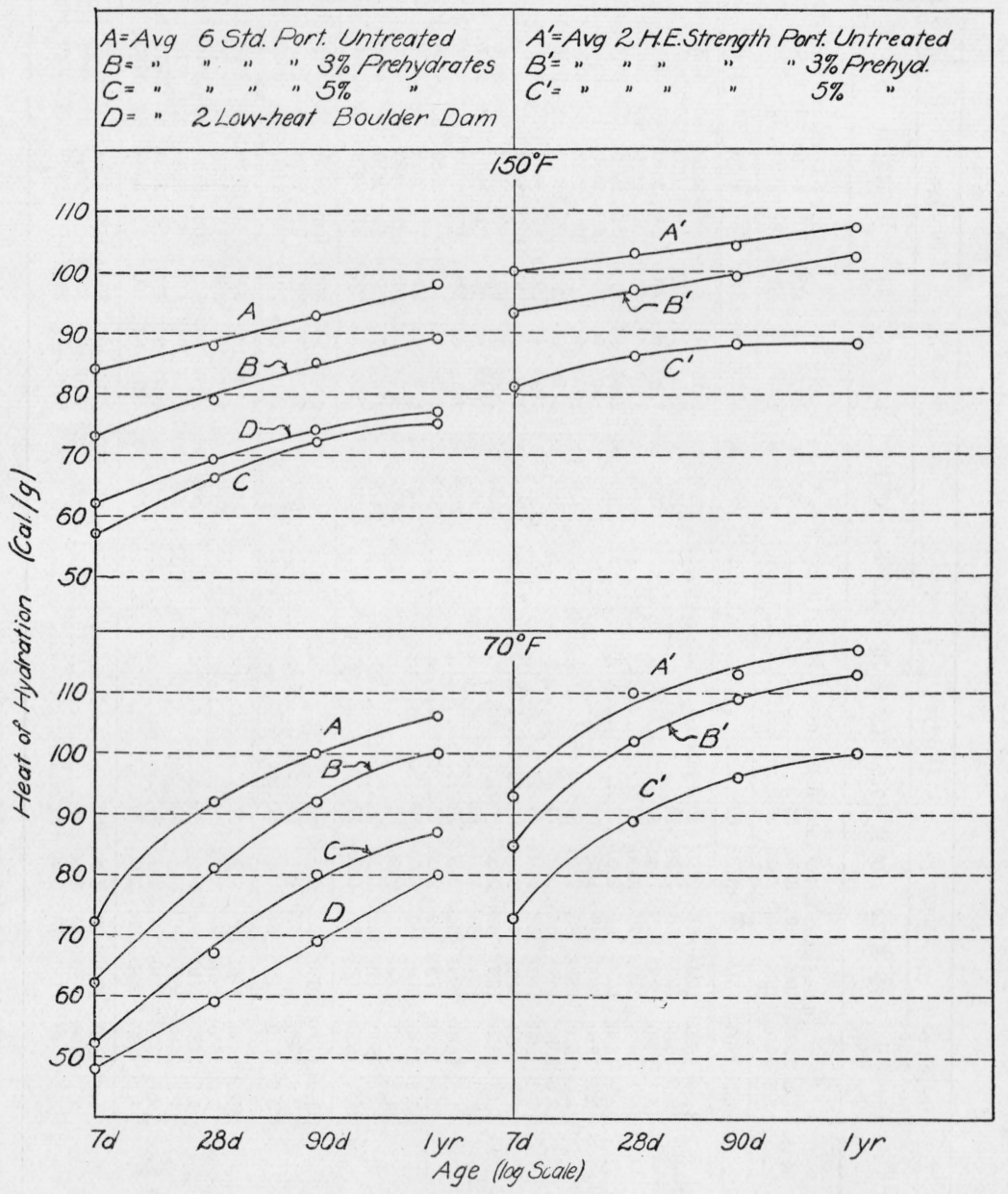

FIGURE 2.-Average heats of hydration of untreated and prehydrated cements for 70 and $150^{\circ} \mathrm{F}$ curing.

three types of cement, are given in table 2. Graphic representations of the individual heats of hydration are shown in figure 1 , and the average heats of hydration of the three types are shown in figure 2 . 
TABLE 2.-Strengths of 3- by 6-inch concrete cylinders, cured at different temperatures and ages, and heats of hydration of cements cured at corresponding temperatures and ages

\begin{tabular}{|c|c|c|c|c|c|c|c|c|c|c|c|c|c|c|c|c|c|c|c|c|c|c|c|c|c|c|c|c|c|}
\hline \multirow{3}{*}{$\begin{array}{l}\text { Cement } \\
\\
\end{array}$} & \multirow{3}{*}{$\begin{array}{c}\text { Type } \\
\text { Low heat } \\
\text { do }\end{array}$} & \multirow{3}{*}{$\begin{array}{c}\text { Ig- } \\
\text { ni- } \\
\text { tion } \\
\text { loss } \\
\\
1.0 \\
1.3\end{array}$} & \multirow{3}{*}{$\begin{array}{l}\text { Spe- } \\
\text { cific } \\
\text { sur- } \\
\text { face } \\
\\
1890 \\
1910\end{array}$} & \multicolumn{4}{|c|}{7 days } & \multicolumn{2}{|c|}{14 days } & \multicolumn{2}{|c|}{21 days } & \multicolumn{4}{|c|}{28 days } & \multicolumn{4}{|c|}{90 days } & \multicolumn{4}{|c|}{1 year } & \multirow{2}{*}{\multicolumn{2}{|c|}{$\begin{array}{l}6 \text { days at } \\
150^{\circ} \mathrm{F} ; \\
51 \text { weeks } \\
\text { at } 70^{\circ} \mathrm{F}\end{array}$}} & \multirow{2}{*}{\multicolumn{2}{|c|}{$\begin{array}{c}27 \text { days at } \\
150^{\circ} \mathrm{F} ; \\
48 \text { weeks } \\
\text { at } 70^{\circ} \mathrm{F}\end{array}$}} & \multirow{2}{*}{\multicolumn{2}{|c|}{$\begin{array}{l}89 \text { days at } \\
150^{\circ} \mathrm{F} ; \\
39 \text { weeks } \\
\text { at } 70^{\circ} \mathrm{F}\end{array}$}} \\
\hline & & & & \multicolumn{2}{|c|}{$70^{\circ} \mathrm{F}$} & \multicolumn{2}{|c|}{$150^{\circ} \mathrm{F}$} & \multirow{2}{*}{ 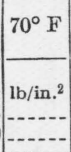 } & \multirow{2}{*}{$150^{\circ} \mathrm{F}$} & \multirow{2}{*}{$70^{\circ} \mathrm{F}$} & \multirow{2}{*}{$\begin{array}{c}150^{\circ} \mathrm{F} \\
\mathrm{b} / \mathrm{in}^{2} \\
-2 \\
\end{array}$} & \multicolumn{2}{|c|}{$70^{\circ} \mathrm{F}$} & \multicolumn{2}{|c|}{$150^{\circ} \mathrm{F}$} & \multicolumn{2}{|c|}{$70^{\circ} \mathrm{F}$} & \multicolumn{2}{|c|}{$150^{\circ} \mathrm{F}$} & \multicolumn{2}{|l|}{$70^{\circ} \mathrm{F}$} & \multicolumn{2}{|c|}{$150^{\circ} \mathrm{F}$} & & & & & & \\
\hline & & & & \begin{tabular}{c|c} 
b/in. 2 & cs \\
660 & \\
370 &
\end{tabular} & \begin{tabular}{r|r}
$\mathrm{cal} / \mathrm{g}$ & 1 \\
49 & \\
46 &
\end{tabular} & $\begin{array}{r}\text { lb/in. } .^{2} \\
2350 \\
2800\end{array}$ & $\begin{array}{r}\mathrm{cal} / \mathrm{g} \\
63 \\
60\end{array}$ & & & & & $\begin{array}{r}\mathrm{Ib} / \mathrm{in} .{ }^{2} \\
1760 \\
1610\end{array}$ & \begin{tabular}{r|r}
$\mathrm{eal} / \mathrm{g}$ & $\mathrm{I}$ \\
60 & \\
57 & \\
\end{tabular} & $\begin{array}{r}\mathrm{Ib} / \mathrm{in}^{2} \\
4090 \\
3380\end{array}$ & \begin{tabular}{|r|}
$\mathrm{cal} / \mathrm{g}$ \\
70 \\
68 \\
\end{tabular} & $\begin{array}{c}\mathrm{lb} / \text { in. }^{2} \\
4180 \\
3590\end{array}$ & $\begin{array}{r}\mathrm{cal} / \mathrm{g} \\
71 \\
66 \\
\end{array}$ & $\begin{array}{r}\mathrm{lb} / \text { in. }^{2} \\
4470 \\
3600\end{array}$ & $\begin{array}{r}\mathrm{eal} / \mathrm{g} \\
74 \\
73 \\
\end{array}$ & $\begin{array}{r}\mathrm{lb} / \mathrm{in} .^{2} \\
5360 \\
4110\end{array}$ & \begin{tabular}{r|r}
$\mathrm{cal} / \mathrm{g}$ & \\
83 & \\
76 &
\end{tabular} & $\begin{array}{r}\text { 1b/in. }{ }^{2} \\
4920 \\
4390\end{array}$ & $\mid \begin{array}{r}\mathrm{cal} / \mathrm{g} \\
78 \\
75\end{array}$ & $\begin{array}{r}\mathrm{lb} / \text { in }^{2} \\
4540 \\
4120\end{array}$ & $\begin{array}{r}\mathrm{cal} / \mathrm{g} \\
82 \\
76\end{array}$ & $\begin{array}{c}\mathrm{lb} / \mathrm{in.}^{2} \\
4500 \\
3670\end{array}$ & 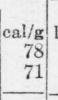 & $\begin{array}{r}\mathrm{lb} / \mathrm{in} .2 \\
4530 \\
3830\end{array}$ & \begin{tabular}{l|l}
$0_{0}^{\mathrm{cal} / \mathrm{g}}$ \\
0 \\
0
\end{tabular} \\
\hline$\nabla \sigma \mathrm{A} \quad \mathrm{B}$ & & 1.2 & 1900 & 515 & 48 & 2570 & 62 & & & & & 1680 & 59 & 3730 & 69 & 3880 & 69 & 4030 & 74 & 4740 & 80 & 4660 & 77 & 4330 & 79 & 4090 & 75 & 4180 & 74 \\
\hline & $\begin{array}{c}\text { Standard } \\
\text { portland. }\end{array}$ & $\left\{\begin{array}{l}.9 \\
2.9 \\
5.1 \\
1.1 \\
2.9 \\
5.2 \\
1.0 \\
3.0 \\
5.3 \\
1.5 \\
2.8 \\
5.3 \\
1.8 \\
2.6 \\
5.1 \\
1.1 \\
3.0 \\
5.4\end{array}\right.$ & \begin{tabular}{|l|}
1680 \\
1640 \\
1630 \\
1850 \\
1880 \\
1840 \\
1510 \\
1580 \\
1560 \\
1860 \\
1850 \\
1880 \\
1680 \\
1680 \\
1650 \\
1630 \\
1590 \\
1690 \\
\end{tabular} & \begin{tabular}{r|}
1680 \\
1510 \\
950 \\
2410 \\
1550 \\
1190 \\
1950 \\
1680 \\
1260 \\
2400 \\
1630 \\
1200 \\
1800 \\
1720 \\
1130 \\
1930 \\
1420 \\
1170
\end{tabular} & \begin{tabular}{l|l|}
61 & \\
56 & \\
45 & 70 \\
64 & 48 \\
86 & 66 \\
58 & \\
79 & 67 \\
50 & 64 \\
62 & 50 \\
75 & \\
59 & \\
52 & \\
\end{tabular} & \begin{tabular}{l|}
2730 \\
1730 \\
1490 \\
3390 \\
2200 \\
1490 \\
2430 \\
2000 \\
1410 \\
2810 \\
2100 \\
1310 \\
2420 \\
2100 \\
1560 \\
2520 \\
1520 \\
1300
\end{tabular} & $\begin{array}{l}80 \\
73 \\
53 \\
87 \\
77 \\
58 \\
89 \\
74 \\
63 \\
84 \\
70 \\
52 \\
79 \\
75 \\
59 \\
83 \\
66 \\
57 \\
\end{array}$ & . & 2700 & 910 & 780 & \begin{tabular}{l|}
2720 \\
2470 \\
1790 \\
4000 \\
2760 \\
2260 \\
3410 \\
2880 \\
2250 \\
3820 \\
2550 \\
2250 \\
3260 \\
2850 \\
2120 \\
3520 \\
2490 \\
2240
\end{tabular} & \begin{tabular}{r|}
77 \\
69 \\
59 \\
93 \\
84 \\
65 \\
104 \\
88 \\
80 \\
96 \\
80 \\
62 \\
86 \\
82 \\
66 \\
98 \\
79 \\
67 \\
\end{tabular} & $\begin{array}{l}2970 \\
2410 \\
1760 \\
3710 \\
2480 \\
1940 \\
2670 \\
2170 \\
1720 \\
2960 \\
2430 \\
1670 \\
2530 \\
2620 \\
1940 \\
3040 \\
2110 \\
1850\end{array}$ & $\begin{array}{l}81 \\
75 \\
61 \\
93 \\
83 \\
68 \\
93 \\
81 \\
69 \\
90 \\
78 \\
61 \\
83 \\
81 \\
68 \\
90 \\
76 \\
65\end{array}$ & $\begin{array}{l}3800 \\
3190 \\
2900 \\
4760 \\
3940 \\
2980 \\
3680 \\
2970 \\
2930 \\
3950 \\
3240 \\
2800 \\
3820 \\
3550 \\
3060 \\
3950 \\
3100 \\
2770\end{array}$ & \begin{tabular}{r|}
88 \\
81 \\
76 \\
103 \\
94 \\
81 \\
109 \\
100 \\
89 \\
102 \\
90 \\
74 \\
97 \\
96 \\
77 \\
102 \\
89 \\
81 \\
\end{tabular} & $\begin{array}{l}3910 \\
3000 \\
2610 \\
4430 \\
2930 \\
2830 \\
3320 \\
2670 \\
2460 \\
3530 \\
2930 \\
2120 \\
2900 \\
2820 \\
2340 \\
3490 \\
2510 \\
2370\end{array}$ & $\begin{array}{r}85 \\
76 \\
\text { a } 66 \\
99 \\
90 \\
76 \\
99 \\
88 \\
77 \\
96 \\
85 \\
66 \\
87 \\
85 \\
74 \\
92 \\
83 \\
72\end{array}$ & $\begin{array}{l}4350 \\
3950 \\
3370 \\
5060 \\
3860 \\
3830 \\
3870 \\
3460 \\
3020 \\
4470 \\
3610 \\
3600 \\
4360 \\
4240 \\
3870 \\
4320 \\
4060 \\
3610\end{array}$ & \begin{tabular}{r|}
94 \\
90 \\
77 \\
109 \\
101 \\
87 \\
116 \\
107 \\
95 \\
106 \\
98 \\
83 \\
103 \\
104 \\
92 \\
108 \\
98 \\
90
\end{tabular} & \begin{tabular}{|l|}
4940 \\
3930 \\
4300 \\
4780 \\
3940 \\
4010 \\
4110 \\
3660 \\
3540 \\
3960 \\
3510 \\
3000 \\
3530 \\
3410 \\
3230 \\
4270 \\
3940 \\
3260 \\
\end{tabular} & \begin{tabular}{|r}
90 \\
83 \\
68 \\
101 \\
94 \\
77 \\
107 \\
90 \\
$\mathrm{a} 79$ \\
100 \\
90 \\
73 \\
92 \\
90 \\
78 \\
$\mathrm{a} 97$ \\
84 \\
74 \\
\end{tabular} & $\begin{array}{l}3540 \\
3250 \\
2440 \\
4570 \\
3500 \\
3440 \\
2960 \\
2540 \\
2380 \\
3710 \\
3430 \\
2650 \\
3680 \\
3490 \\
3580 \\
3700 \\
3290 \\
2830\end{array}$ & \begin{tabular}{|r}
93 \\
87 \\
73 \\
103 \\
$\mathrm{a} 96$ \\
84 \\
105 \\
96 \\
83 \\
102 \\
95 \\
81 \\
95 \\
100 \\
87 \\
103 \\
94 \\
85
\end{tabular} & $\begin{array}{l}3630 \\
2980 \\
2300 \\
4400 \\
3110 \\
2940 \\
3090 \\
2710 \\
2260 \\
3760 \\
2900 \\
2380 \\
3420 \\
3150 \\
2690 \\
3690 \\
2780 \\
2680 \\
\end{array}$ & \begin{tabular}{|r|}
85 \\
82 \\
66 \\
102 \\
94 \\
78 \\
101 \\
89 \\
78 \\
99 \\
91 \\
75 \\
93 \\
91 \\
78 \\
96 \\
86 \\
77 \\
\end{tabular} & $\begin{array}{l}4370 \\
3270 \\
2610 \\
4870 \\
3530 \\
3120 \\
3470 \\
2920 \\
2650 \\
3980 \\
3250 \\
2380 \\
3270 \\
3260 \\
2600 \\
3940 \\
2850 \\
2620\end{array}$ & \begin{tabular}{|r}
86 \\
84 \\
67 \\
98 \\
93 \\
74 \\
102 \\
90 \\
77 \\
96 \\
89 \\
70 \\
70 \\
88 \\
90 \\
75 \\
94 \\
78 \\
74
\end{tabular} \\
\hline & & & \begin{tabular}{|l|}
1700 \\
1700 \\
1710 \\
\end{tabular} & $\begin{array}{l}2030 \\
1590 \\
1150 \\
\end{array}$ & \begin{tabular}{l|}
72 \\
62 \\
52 \\
\end{tabular} & & & & & & & & $\begin{array}{l}92 \\
81 \\
67 \\
\end{array}$ & & $\begin{array}{l}88 \\
79\end{array}$ & & $\begin{array}{r}100 \\
92 \\
80 \\
\end{array}$ & & & & $\begin{array}{r}106 \\
100 \\
87\end{array}$ & & $\begin{array}{r}98 \\
89 \\
75 \\
\end{array}$ & & $\begin{array}{r}100 \\
94 \\
82 \\
\end{array}$ & & & & ) \\
\hline & High-early & $\left\{\begin{array}{l}1.2 \\
3.0 \\
5.3 \\
1.8 \\
2.8 \\
4.9 \\
\end{array}\right.$ & \begin{tabular}{|l|}
2500 \\
2500 \\
2420 \\
2540 \\
2590 \\
2590 \\
\end{tabular} & $\begin{array}{l}2880 \\
2870 \\
2410 \\
2580 \\
2480 \\
1880\end{array}$ & \begin{tabular}{|r|}
105 \\
93 \\
80 \\
81 \\
77 \\
66
\end{tabular} & $\begin{array}{l}3190 \\
3030 \\
2640 \\
3830 \\
3000 \\
2700\end{array}$ & \begin{tabular}{|r|}
107 \\
98 \\
85 \\
93 \\
88 \\
76 \\
\end{tabular} & 3590 & 3760 & 3750 & 3760 & \begin{tabular}{l|}
3860 \\
3840 \\
3280 \\
4400 \\
3800 \\
3720
\end{tabular} & $\begin{array}{r}119 \\
109 \\
94 \\
100 \\
94 \\
83\end{array}$ & & $\begin{array}{r}109 \\
101 \\
87 \\
96 \\
92 \\
84\end{array}$ & & $\begin{array}{r}122 \\
115 \\
100 \\
104 \\
103 \\
92\end{array}$ & $\begin{array}{l}3610 \\
3370 \\
3150 \\
3950 \\
3620 \\
3600\end{array}$ & $\begin{array}{r}111 \\
102 \\
91 \\
97 \\
96 \\
84\end{array}$ & & \begin{tabular}{r|r}
125 & 118 \\
103 & 109 \\
107 & \\
96 &
\end{tabular} & $\begin{array}{l}4300 \\
3950 \\
3570 \\
4070 \\
4130 \\
4320 \\
\end{array}$ & $\begin{array}{r}114 \\
106 \\
90 \\
100 \\
97 \\
85\end{array}$ & $\begin{array}{l}3750 \\
3430 \\
3280 \\
4450 \\
3940 \\
3810\end{array}$ & $\begin{array}{r}114 \\
109 \\
93 \\
105 \\
101 \\
91\end{array}$ & $\begin{array}{l}3780 \\
3460 \\
3220 \\
4480 \\
4010 \\
3670\end{array}$ & \begin{tabular}{|r|}
112 \\
107 \\
90 \\
102 \\
100 \\
89
\end{tabular} & $\begin{array}{l}4080 \\
3760 \\
3320 \\
4530 \\
3880 \\
4000\end{array}$ & $\begin{array}{r}112 \\
107 \\
90 \\
100 \\
96 \\
89\end{array}$ \\
\hline Avg I, & & $\left\{\begin{array}{l}1.5 \\
2.9 \\
5.1\end{array}\right.$ & \begin{tabular}{|l|}
2520 \\
2550 \\
2510
\end{tabular} & $\begin{array}{l}2730 \\
2680 \\
2150\end{array}$ & \begin{tabular}{|l|}
93 \\
85 \\
73
\end{tabular} & $\begin{array}{l}3510 \\
3040 \\
2670\end{array}$ & $\begin{array}{r}100 \\
93 \\
81\end{array}$ & & & & & $\begin{array}{l}4130 \\
3820 \\
3500\end{array}$ & $\begin{array}{r}110 \\
102 \\
89\end{array}$ & $\begin{array}{l}3630 \\
3510 \\
3020\end{array}$ & \begin{tabular}{|r|}
103 \\
97 \\
86
\end{tabular} & $\begin{array}{l}3940 \\
3950 \\
3800\end{array}$ & $\begin{array}{r}113 \\
109 \\
96\end{array}$ & $\begin{array}{l}3780 \\
3500 \\
3380\end{array}$ & \begin{tabular}{r|}
104 \\
99 \\
88
\end{tabular} & $\begin{array}{l}4240 \\
4070 \\
3840\end{array}$ & $\begin{array}{l}117 \\
113 \\
100\end{array}$ & \begin{tabular}{|l|}
4190 \\
4040 \\
3950
\end{tabular} & $\begin{array}{r}107 \\
102 \\
88\end{array}$ & $\begin{array}{l}4100 \\
3690 \\
3550\end{array}$ & $\begin{array}{r}110 \\
105 \\
92\end{array}$ & & $\begin{array}{r}107 \\
104 \\
90\end{array}$ & $\begin{array}{l}4310 \\
3820 \\
3660\end{array}$ & $\begin{array}{r}106 \\
102 \\
90\end{array}$ \\
\hline
\end{tabular}

a Extrapolated values necessitated by breakage of specimen vials. 
These results show that increasing the amounts of prehydration caused successive reductions in the heats of hydration at all ages of both the standard portland and the high-early-strength cements. The 1 -year value of the 3-percent prehydrate of cement $\mathrm{G}$ constituted a single exception to that behavior, but in forming that particular prehydrate, the loss on ignition (which already was 1.8 percent) was increased only 0.8 percent. The average reduction in the heat of hydration at 7 days of all the standard portland cements was, for the 3 -percent prehydration, approximately 13 percent at both curing temperatures; the least individual reduction (other than cement $\mathrm{G}$ ) was 8 percent. The average reduction of the 3-percent prehydrates of the high-early-strength cements was approximately two-thirds that of the same prehydrates of the standard portland cements.

The 5-percent prehydration of the standard portland cements caused an average reduction at 7 days of approximately 30 percent at both curing temperatures, the lowest individual reduction being 22 percent. The average reduction for the high-early-strength cements caused by the 5 -percent prehydration was approximately 20 percent for both curing temperatures.

At 1 year the reductions caused by the respective prehydrations were approximately one-half the reductions at 7 days.

(b) REDUCTION IN HEAT OF HYDRATION PER PERCENT INCREASE IN LOSS ON IGNITION

The calories per gram reduction in the heats of hydration caused by each 1-percent increase in the loss on ignition were calculated for the two series of prehydrates and the results are given in table 3. These results show that the calories per gram reduction vary widely between cements for each percent increase in ignition loss, and that neither series of prehydrates uniformly affects a greater reduction of the heat than the other series. In general, the reduction in heat is greater at the earlier ages than at the later ages, this trend being similar for both curing temperatures.

TABLE 3.-Reduction in heat of hydration for each percent increase of ignition loss [Calories per gram]

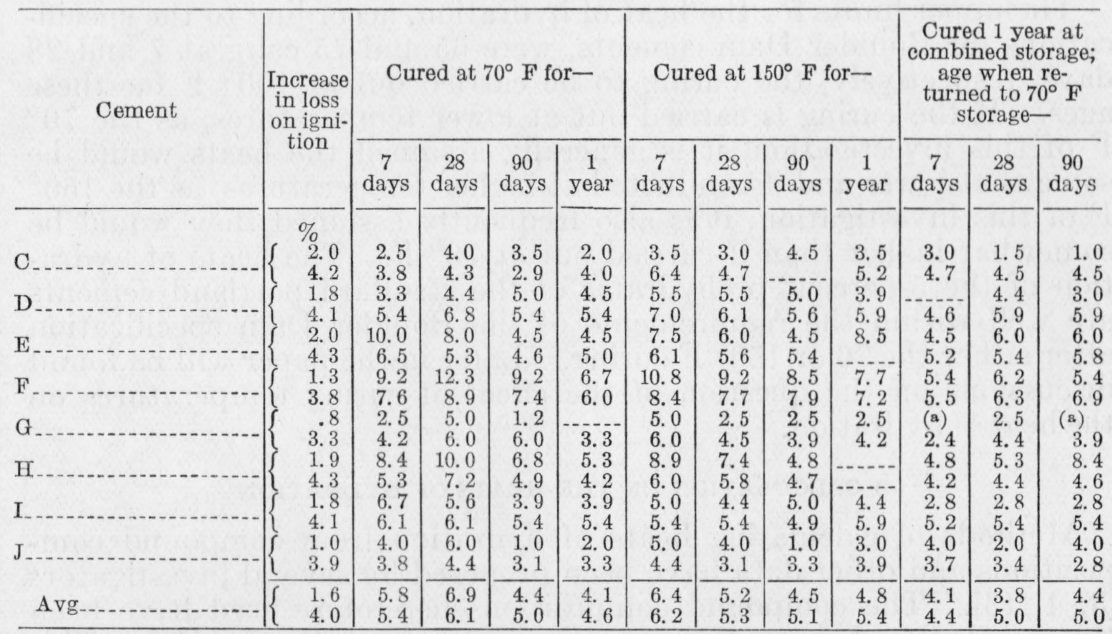

a Gain.

$60348-36-8$ 
A comparison of the values given in table 3 with the compound compositions of the cements fails to reveal any correlation between the reduction in heat and the amount of any one compound in the cements. Data on heats of solution also indicate that the reactions during steam treatment are not confined chiefly to one compound. Thus the reduction in heat of solution for each percent increase of loss on ignition by prehydration averaged $5.1 \mathrm{cal} / \mathrm{g}$ for the 3 -percent series of prehydrates, and $4.4 \mathrm{cal} / \mathrm{g}$ for the 5-percent series. No individual value varied more than $0.9 \mathrm{cal}$ from the average. Hence, the reaction was approximately the same for each cement, regardless of compound composition.

Davis and co-workers [4] from studies of aged commercial cements having high ignition losses suggest that for each percent ignition loss a correction of $-6 \mathrm{cal} / \mathrm{g}$ be made in calculating the heat of hydration for the early ages and a correction of $-3 \mathrm{cal} / \mathrm{g}$ be made for the 1-year value. The results of the present investigation, as presented in table 3 , also indicate that a representative average value for 7 and 28 days is $-6 \mathrm{cal} / \mathrm{g}$, but for 1 year $-4 \mathrm{cal} / \mathrm{g}$ is indicated. For individual cements, however, these values may need be reduced by 50 percent or increased by 100 percent.

\section{(c) COMPARISON OF PREHYDRATED CEMENTS WITH BOULDER DAM CEMENTS}

The 3-percent prehydrates of the standard portland and high-earlystrength cements in all cases had considerably higher heats of hydration than the Boulder Dam cements. Of the 5-percent prehydrates of the standard portland cements, however, at the $70^{\circ} \mathrm{F}$ curing, three of the cements had 7-day heats of hydration comparable to the heats of the Boulder Dam cements. The average, however, of the standard portland cements cured at $70^{\circ} \mathrm{F}$ exceeded the average of the Boulder Dam cements. All the 5-percent prehydrates of the standard portland cements stored at $150^{\circ} \mathrm{F}$ had heats of hydration as low as or lower than the Boulder Dam cements cured at that temperature. The 5-percent prehydrates of the high-early-strength cements had, at both curing temperatures, higher heats than the Boulder Dam cements.

The upper limits for the heat of hydration, according to the specifications for Boulder Dam cements, were 65 and $75 \mathrm{cal} / \mathrm{g}$ at 7 and 28 days, respectively, the curing to be carried out at $100^{\circ} \mathrm{F}$ for these ages. If the curing is carried out at lower temperatures, as the $70^{\circ}$ $\mathrm{F}$ of this investigation, it is generally assumed the heats would be somewhat lower and if conducted at higher temperatures, as the $150^{\circ}$ $\mathrm{F}$ of this investigation, it is also frequently assumed they would be somewhat higher than if carried out at $70^{\circ} \mathrm{F}$. The heats of hydration of the 5-percent prehydrates of the standard portland cements are well within the requirements of the Boulder Dam specification after either the 70 or $150^{\circ} \mathrm{F}$ curing. Later in the paper will be found discussions on the question of the effect of curing temperatures on the heat of hydration.

\section{(d) CALCULATION OF THE HEATS OF HYDRATION}

Methods of calculating heats of hydration from compound compositions and other data have been proposed by several investigators $[3,4,13]$. The compound compositions heretofore used have been those calculated according to the method of Bogue [11]. This 
method assumes that the clinker is completely crystalline and that equilibrium is maintained between liquid and solid during cooling. Lea and Parker [8] have shown that the liquid present at the clinkering temperature does not maintain equilibrium with the preexisting solid on cooling and, therefore, propose corrections for the Bogue values. These proposed corrections of the calculated values are based on the assumption that (a) the liquid cools to a glass, or (b) the liquid crystallizes out independently at $1,400^{\circ} \mathrm{C}$. The compound compositions of the cements used in this investigation were calculated by all three methods and are given in table 1.

All three sets of compound compositions were used in calculating the heats of hydration of the cements and prehydrates, using factors and corrections proposed by the Bureau of Reclamation [12]. These factors for the calories per gram of heat evolved for each percent of compound present in the cement are as follows:

\begin{tabular}{|c|c|c|c|c|}
\hline Age, in days & $\mathrm{C}_{3} \mathrm{~S}$ & $\mathrm{C}_{2} \mathrm{~S}$ & $\mathrm{C}_{3} \mathrm{~A}$ & $\mathrm{C}_{4} \mathrm{AF}$ \\
\hline $\begin{array}{l}7 \\
28 \\
90\end{array}$ & $\begin{array}{l}+1.17 \\
+1.32 \\
+1.26\end{array}$ & $\begin{array}{r}+0.18 \\
+.43 \\
+.63\end{array}$ & $\begin{array}{l}+2.67 \\
+2.54 \\
+2.43\end{array}$ & $\begin{array}{l}+0.23 \\
+.23 \\
+.37\end{array}$ \\
\hline
\end{tabular}

Corrections for loss on ignition and fineness were made as follows: for each percent ignition loss above 1 percent, 12 percent of the heat of hydration was subtracted, and for each $100 \mathrm{~cm}^{2}$ of specific surface above $1,200 \mathrm{~cm}^{2}$ the following amounts were added to the heats of hydration: at 7 days, 3 percent; at 28 days, 2.25 percent; and at 90 days, 1.50 percent. These calculated heats of hydration are listed in table 4 , together with the observed heats of hydration for the same ages for both the 70 and $150^{\circ} \mathrm{F}$ curing.

TABLE 4.-Comparison of calculated and observed heat of hydration values for 7,28 , and 90 days

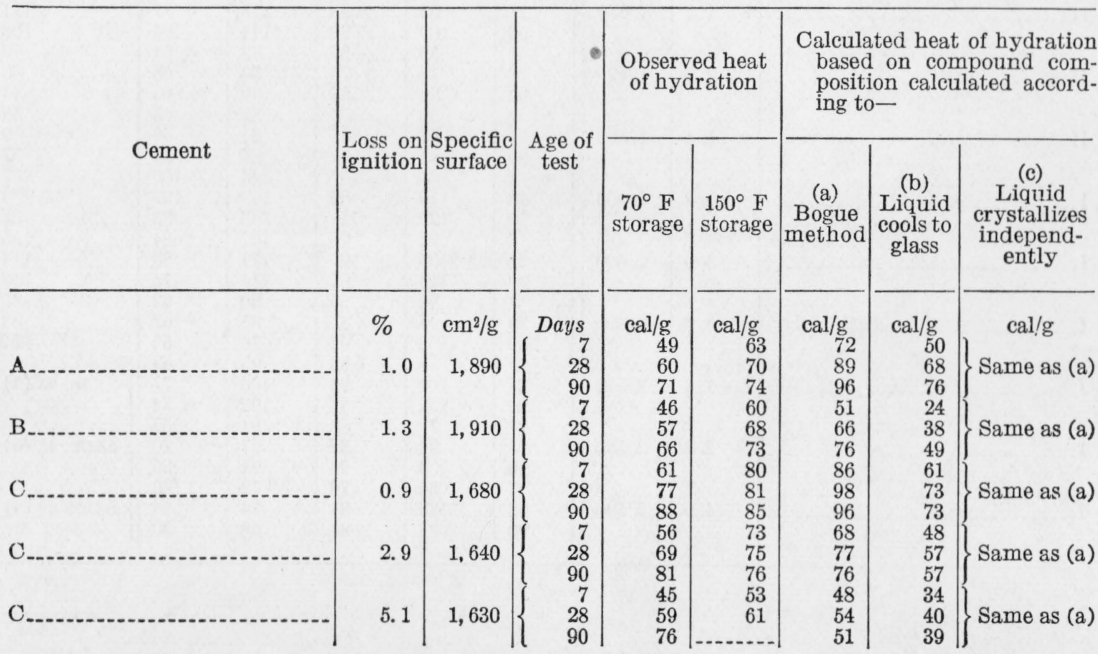


TABLE 4.-Comparison of calculated and observed heat of hydration values for 7, 28 and 90 days-Continued

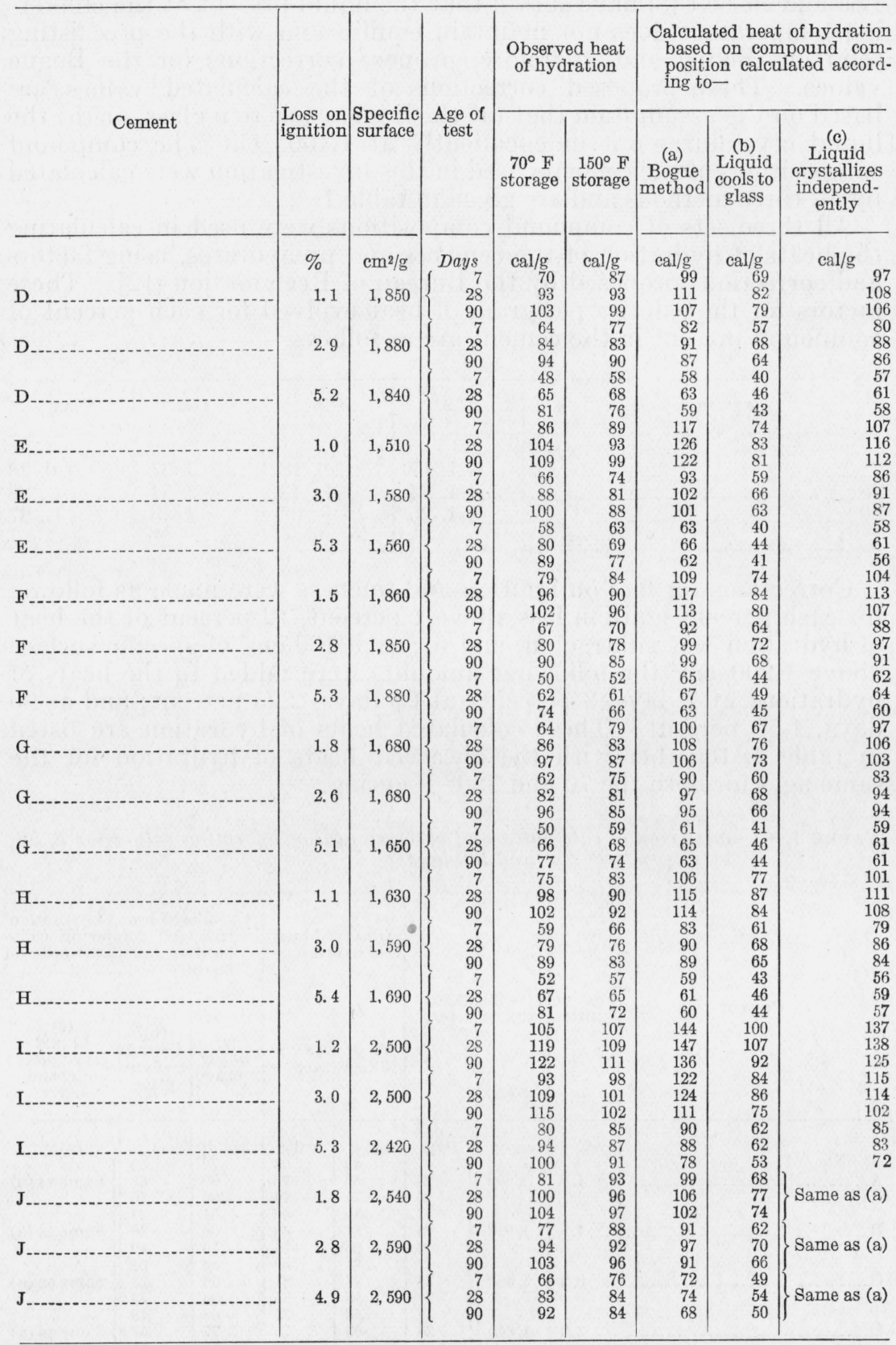


As can be seen from the tabulated results, the values calculated from the compound compositions according to Bogue, and the values calculated by assuming that the liquid crystallizes independently, are, in general, higher than the observed results, and the results calculated by assuming that the liquid cools to a glass are, in general, lower than the observed results. In no case, however, is there good agreement at all three ages between the calculated and observed values for either the 70 or $150^{\circ} \mathrm{F}$ storage.

Whether the lack of agreement is the fault of the factors, the corrections, or the calculated compound compositions, or a combination of all three, the investigation did not undertake to show. It might be noted, however, that in the present work the reduction in heat for each percent increase in the ignition loss of the cement was found, when expressed on a percentage basis, to be approximately 8 percent for 7 and 28 days and 5 percent at 90 days. Apparently the correction factor that was used (12 percent) is too high.

\section{EFFECTS OF CURING TEMPERATURE ON HEATS OF HYDRATION}

(a) CONTINUOUS STORAGE AT 70 AND $150^{\circ} \mathrm{F}$

It is interesting to note that at 7 days the higher curing temperature produced higher heats of hydration for all the cements than the $70^{\circ} \mathrm{F}$ curing. At the age of 28 days, however, the high-early-strength and the standard portland cements both had lower heats of hydration at the $150^{\circ} \mathrm{F}$ curing temperature than at the $70^{\circ} \mathrm{F}$. In general, these two types of cements, with increasing age, had increasingly greater heats of hydration at the lower curing temperature than at the higher temperature. The Boulder Dam cements, however, had greater heats of hydration at the higher curing temperature, not only at 7 days but also at 28 and 90 days. At 1 year the heat evolved at the lower curing temperature had exceeded that of the higher temperature, but by only a very small amount.

\section{(b) COMBINED STORAGE}

The results for heat of hydration obtained from the combined storage tests (i. e., the tests in which respective specimens were cured 24 hours at $70^{\circ} \mathrm{F}$, then at $150^{\circ} \mathrm{F}$ for either 6,27 , or 89 days, then placed back at $70^{\circ} \mathrm{F}$ storage for test at the total age of 1 year) differ considerably from the results obtained from the continuous storage at $70^{\circ} \mathrm{F}$. Of the specimens stored at $150^{\circ} \mathrm{F}$ for the 6 -day period, before returning to the $70^{\circ} \mathrm{F}$ storage, the standard portland cements show an average decrease of 5.7 percent and the high-early-strength cements show an average decrease of 7.1 percent from the average value found for the continuous storage at $70^{\circ} \mathrm{F}$ for 1 year. The corresponding prehydrated specimens are affected approximately the same by this type of storage. The Boulder Dam cements show practically no decrease in heat in the combined-storage tests compared with the continuous-storage tests.

The cements cured at $150^{\circ} \mathrm{F}$ for 27 days, then at $70^{\circ} \mathrm{F}$ for the rest of the year, show somewhat greater decrease from the corresponding values obtained at the continuous storage at $70^{\circ} \mathrm{F}$. The portland cements show an average decrease of 7.4 percent, the 3-percent prehydrates an average decrease of 11.0 percent and the 5-percent pre- 
hydrate an average decrease of 13.7 percent. The high-earlystrength cements had an average decrease of 8.5 percent from the value obtained at $70^{\circ} \mathrm{F}$ continuous storage; in this series the partial hydrates do not differ greatly from the original cements. In general, the values for heat of hydration obtained for the cements stored for 27 days at $150^{\circ} \mathrm{F}$ and then returned to $70^{\circ} \mathrm{F}$ for the remainder of the year, are very similar to the values obtained for a continuous storage at $150^{\circ} \mathrm{F}$ for the full year. The storage for 89 days at $150^{\circ} \mathrm{F}$ before returning to the $70^{\circ} \mathrm{F}$ storage caused even greater reduction in the heat of hydration for both the portland cements and the high-earlystrength cements, as well as for their corresponding partial hydrates. Here, again, the prehydrates show somewhat greater reduction in heat than the corresponding untreated cements. In general, the cements that were cured at $150^{\circ} \mathrm{F}$ for 27 days or longer show as great, or greater, reduction in heat of hydration than if cured continuously at $150^{\circ} \mathrm{F}$ for the entire year.

Stenzel and Morris [10] found that a low-heat cement of the type used in Boulder Dam, cured continuously at $212^{\circ} \mathrm{F}$, gave approximately the same heat of hydration at 14 days as that obtained in 6 months of standard curing. They suggest that "when it is desirable to know the ultimate heat developed by a cement, a curing temperature of $212^{\circ} \mathrm{F}$ would be advantageous in greatly accelerating the reaction." The results of this study likewise indicate that the 1-year heats of the Boulder Dam cements are but slightly affected by the curing temperature. The rest of the cements, however, show considerable difference in the amount of heat evolved at the two storage temperatures, in some cases the results being as much as 18 percent lower at the $150^{\circ}$ storage than at the $70^{\circ} \mathrm{F}$ storage. These results indicate, therefore, that the $212^{\circ} \mathrm{F}$ curing would not give a true index of the ultimate heat of hydration of the portland or high-earlystrength cements.

(c) STUDY OF DIFFERENCES IN HEAT EVOLUTION AT HIGH AND LOW CURING TEMPERATURES

Results given in table 5 and figure 3 show the effects on the heat of hydration at different ages caused by regrinding a cement to a high degree of fineness, and by curing cement specimens at $45^{\circ} \mathrm{F}$ as well as at 70 and $150^{\circ} \mathrm{F}$. These results show that the heat evolved at the $45^{\circ} \mathrm{F}$ curing exceeded the heat evolved at the $150^{\circ} \mathrm{F}$ curing at an earlier age for the reground cement than for the original.

TABLE 5.-Effect of 45,70 , and $150^{\circ} \mathrm{F}$ curing on heat of hydration

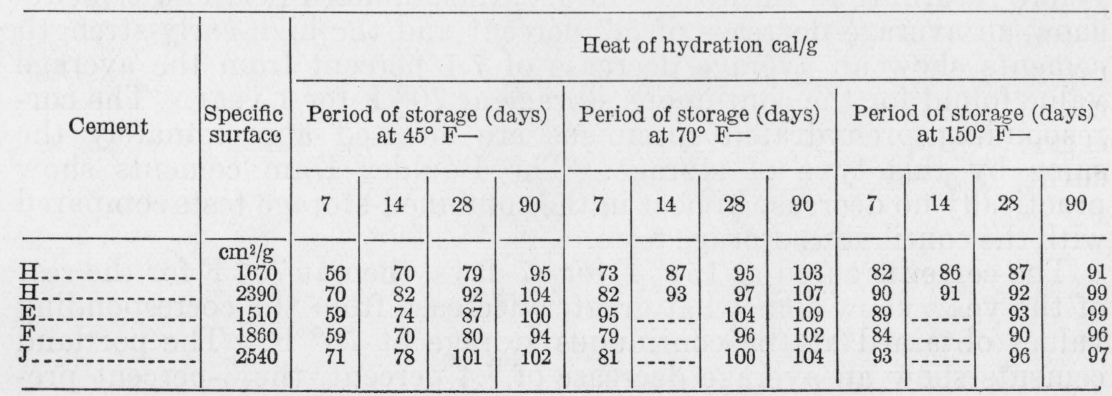


Also, as can be seen from figure 2, the time required for the heat evolved at the $70^{\circ} \mathrm{F}$ curing to exceed the heat evolved at the $150^{\circ}$ F curing was least for the high-early-strength cements, greater for the standard portland, and considerably greater for the Boulder Dam cements. Successive prehydrations also increased the age at which the heat evolved at $70^{\circ} \mathrm{F}$ exceeded that evolved at $150^{\circ} \mathrm{F}$.

It is known [13] that the finer a cement is ground the greater is the early slope of the time-temperature curve, also as the curing temperature is raised the early slope of the time-temperature curve becomes greater [14]. Then, too, the time-temperature curve for high-early-strength cements has greater early slope than that of the standard portland cements, and prehydration decreases this slope [1]. These same factors increase the early slope of the time-temperature curve and also decrease the time required for the heat of hydration

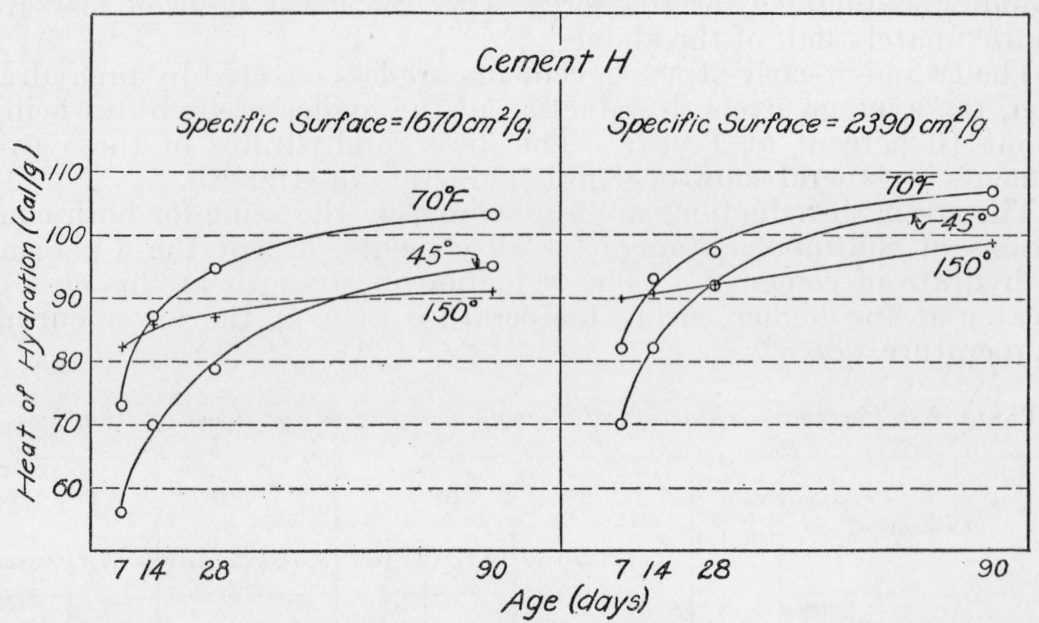

FIgURE 3.-Heats of hydration at three different curing temperatures of cement $\mathrm{H}$ ground to two degrees of fineness.

curve obtained at $70^{\circ} \mathrm{F}$ to cross the curve obtained at $150^{\circ} \mathrm{F}$. It appears possible, therefore, that some relationship may exist between these two phenomena. Since an increased slope of the time-temperature curve indicates greater intensity of action during the initial hydration (setting), it is passible that when this activity is sufficiently great (caused by higher initial-storage temperature, grinding to greater fineness, or by using a quick-setting cement) the process of "setting" is speeded up. The hydrated material then precipitates so rapidly that unhydrated particles are coated with hydrated set material of such density that further hydration of the unhydrated particle is greatly inhibited. Hence, the lower evolution of heat at the higher curing temperatures for the later ages. 


\section{COMPRESSIVE-STRENGTH RESULTS}

\section{EFFECT OF PREHYDRATION ON THE COMPRESSIVE STRENGTH OF CONCRETE}

The compressive strength results for concrete made of the cements as received, prehydrated to 3 - and 5-percent ignition loss, and cured at $70^{\circ} \mathrm{F}, 150^{\circ} \mathrm{F}$, and in combined storage are given in table 2 and figure 1.

Prehydration of these cements, in general, caused a reduction in strength, the higher prehydration resulting in the greater reduction. These reductions in strength are more pronounced, in terms of percentage, at the early ages, the average decrease of the six standard portland cements for the series with the higher ignition loss being about 40 percent at 7 days and about 20 percent at 1 year. Corresponding reductions for the series with the lower ignition loss are approximately half of the above.

The two high-early-strength cements are less affected by prehydration, the average strength reduction of the higher prehydrates being about 10 percent at 1 year. The lower prehydrates of these two cements in general show negligible reduction in strength.

The strength reductions are approximately the same for both conditions of continuous storage for all cements, except the 3-percent prehydrate of cement C. The reduction in strength in this case is greater at the higher curing temperature than at the lower curing temperature.

TABLE 6.-Percentage reduction of strength per percent increased ignition loss

\begin{tabular}{|c|c|c|c|c|c|c|c|c|c|}
\hline \multirow{2}{*}{ Cement } & \multirow{2}{*}{$\begin{array}{c}\text { In- } \\
\text { creased } \\
\text { ignition } \\
\text { loss }\end{array}$} & \multicolumn{4}{|c|}{ Cured at $70^{\circ} \mathrm{F}$ for- } & \multicolumn{4}{|c|}{ Cured at $150^{\circ} \mathrm{F}$ for- } \\
\hline & & 7 days & 28 days & 90 days & 1 year & 7 days & 28 days & 90 days & 1 year \\
\hline $\begin{array}{l}\text { D. } \\
\mathrm{E}_{\ldots} \\
\mathrm{F}_{\ldots} \\
\mathrm{G} . \\
\mathrm{H} .\end{array}$ & $\left\{\begin{array}{c}\% \\
2.0 \\
4.2 \\
1.8 \\
4.1 \\
1.9 \\
4.2 \\
1.3 \\
3.8 \\
.8 \\
3.3 \\
1.9 \\
4.3\end{array}\right.$ & $\begin{array}{r}\% \\
5 \\
10 \\
20 \\
12 \\
7 \\
8 \\
25 \\
13 \\
6 \\
11 \\
14 \\
9\end{array}$ & $\begin{array}{r}\% \\
5 \\
8 \\
17 \\
11 \\
8 \\
8 \\
25 \\
11 \\
16 \\
11 \\
15 \\
8\end{array}$ & $\begin{array}{r}\% \\
8 \\
6 \\
10 \\
9 \\
10 \\
5 \\
14 \\
8 \\
9 \\
6 \\
11 \\
7\end{array}$ & $\begin{array}{r}\% \\
5 \\
5 \\
13 \\
6 \\
6 \\
5 \\
15 \\
5 \\
3 \\
3 \\
3 \\
4\end{array}$ & $\begin{array}{r}\% \\
18 \\
11 \\
20 \\
14 \\
9 \\
10 \\
19 \\
14 \\
16 \\
11 \\
21 \\
11\end{array}$ & $\begin{array}{r}\% \\
9 \\
10 \\
18 \\
12 \\
10 \\
9 \\
14 \\
12 \\
+4 \\
7 \\
16 \\
9\end{array}$ & $\begin{array}{r}\% \\
12 \\
8 \\
19 \\
9 \\
11 \\
6 \\
13 \\
11 \\
4 \\
6 \\
15 \\
7\end{array}$ & $\begin{array}{r}\% \\
10 \\
3 \\
10 \\
4 \\
6 \\
3 \\
9 \\
6 \\
4 \\
3 \\
4 \\
6\end{array}$ \\
\hline Avg for $\mathrm{C}$ to $\mathrm{H}$. & $\left\{\begin{array}{l}1.6 \\
4.0\end{array}\right.$ & $\begin{array}{l}13 \\
10\end{array}$ & $\begin{array}{l}14 \\
10\end{array}$ & $\begin{array}{r}10 \\
7\end{array}$ & $\begin{array}{l}7 \\
5\end{array}$ & $\begin{array}{l}17 \\
12\end{array}$ & $\begin{array}{l}10 \\
10\end{array}$ & $\begin{array}{r}12 \\
8\end{array}$ & $\begin{array}{l}7 \\
4\end{array}$ \\
\hline $\begin{array}{l}\mathrm{I} \\
\mathrm{I}\end{array}$ & $\left\{\begin{array}{l}1.8 \\
4.1 \\
1.0 \\
3.1\end{array}\right.$ & $\begin{array}{l}0 \\
4 \\
4 \\
9\end{array}$ & $\begin{array}{r}0 \\
4 \\
14 \\
5\end{array}$ & $\begin{array}{l}0 \\
1 \\
0 \\
1\end{array}$ & $\begin{array}{l}2 \\
2 \\
4 \\
3\end{array}$ & $\begin{array}{r}3 \\
4 \\
20 \\
10\end{array}$ & $\begin{array}{l}3 \\
4 \\
1 \\
6\end{array}$ & $\begin{array}{l}4 \\
3 \\
8 \\
3\end{array}$ & $\begin{array}{r}4 \\
4 \\
+1 \\
+2\end{array}$ \\
\hline Avg for I, J... & $\left\{\begin{array}{l}1.4 \\
3.6\end{array}\right.$ & $\begin{array}{l}2 \\
7\end{array}$ & $\begin{array}{l}7 \\
5\end{array}$ & $\begin{array}{l}0 \\
1\end{array}$ & $\begin{array}{l}3 \\
3\end{array}$ & $\begin{array}{r}12 \\
7\end{array}$ & $\begin{array}{l}2 \\
5\end{array}$ & $\begin{array}{l}6 \\
3\end{array}$ & $\begin{array}{l}2 \\
1\end{array}$ \\
\hline
\end{tabular}

The reductions in strength for both series of prehydrates were calculated to percentage reduction in strength per percent of increased ignition loss. The results are given in table 6 . It is to be noted that in the calculation of these results small errors in strength for the 3-percent prehydrate cause large errors in the calculated values. Hence, in the 3-percent prehydrates, there are a number of erratic 
values at different ages. The general trends for individual cements are more uniform for the 5-percent prehydrates.

The percentage reductions are in general greatest at 7 days and decrease with age for both conditions of curing.

With the exception of the two high-early-strength cements and several of the values in cements $\mathrm{C}$ and $\mathrm{E}$, the 3 -percent prehydrates show greater strength reductions per percent increase in ignition loss than the 5-percent prehydrates.

It is possible that the greater percentage reduction shown by the 3 -percent prehydrates is due to a greater percentage of combined water per percent of ignition loss. From Meyers' [2] results on one cement it is observed that the percentage of combined water (per percent of ignition loss) increases with decreasing ignition losses.

\section{EFFECT OF COMBINED STORAGE ON STRENGTH}

Concrete cured initially at $150^{\circ} \mathrm{F}$, with later storage at $70^{\circ} \mathrm{F}$, in general gives lower 1-year strength than when cured continuously at either 70 or $150^{\circ} \mathrm{F}$. Davis and co-workers [4] reported similar effects on concrete cured at $110^{\circ} \mathrm{F}$.

Of the three ages of initial curing at $150^{\circ} \mathrm{F}$ the 27 days of initial storage at that temperature, resulted, in general, in the lowest 1-year strengths for the Boulder Dam and standard portland cements. The variations in the 1-year strengths for any given cement or prehydrate under combined storage are, on the whole, however, within the experimental error.

\section{COMPARISON OF UNTREATED AND PREHYDRATED CEMENTS WITH BOULDER DAM CEMENTS}

Comparing the strength of the Boulder Dam type of cement with the strength of the prehydrates of the two other types of cements, it will be noted that at 7 days at $70^{\circ} \mathrm{F}$ the average of the Boulder Dam cements is but one-half and one-fourth, respectively, of the average strength of the 5-percent prehydrates of the standard and high-early-strength cements; at 28 days the Boulder Dam cements are still lower, but by 90 days they have exceeded the strength of the other cements. Compared with the 3-percent prehydrates the Boulder Dam cement strengths are relatively lower than when compared with the strengths of the 5-percent prehydrates. Although the strengths of the Boulder Dam cements when cured at 1 year at $70^{\circ} \mathrm{F}$ are considerably better than the strengths of either of the prehydrates of the other types of cement, it should be noted that the strength of one Boulder Dam cement is of the same order as the untreated cements and the other Boulder Dam cement is distinctly better. It is hence evident that such high-silica cements as those of the Boulder Dam type show most excellent strength increases with age, the average increase at 1 year being about 8 times the 7-day strength. But with the standard type of cement the year strength averages about 3 times the 7-day strength, while with the high-early cements it averages somewhat less than twice the 7-day strength.

This relation for the three types of cement is somewhat different for the $150^{\circ} \mathrm{F}$ curing. The Boulder Dam type of cement develops much more strength at early ages at higher temperature than do the two other types. But this rate is not maintained at the late ages. The 
increase between the 7-day and 1-year strength of the Boulder Dam cements is but 0.85 that of the 7 -day strength, while for the standard cements it is 1.5 , and for the high-early-strength cements it is 0.5 .

In resumé, from the strength viewpoint, the prehydrated cements of either the standard or high-early-strength type are distinctly better at 7 days, if cured at $70^{\circ} \mathrm{F}$ than the Boulder Dam type; cured at $150^{\circ} \mathrm{F}$ the strengths of the latter are slightly above those of the prehydrated standard cements and slightly below those of the prehydrated high-early-strength type. This relation changes somewhat with age, and while all types at the age of a year show good strength gains at both temperatures, the high-silica Boulder Dam cements have gained strength at such a greater rate that they are distinctly stronger than the others.

\section{COMPARISON OF HEAT AND STRENGTH RESULTS}

\section{CONTINUOUS STORAGE AT 70 AND $150^{\circ} \mathrm{F}$}

Although, as shown in figure 1 , the heats of hydration and the strengths both increase with age, no mathematical relationship exists between the heat and strength data for these cements. This is to be expected because the compounds in the cement do not contribute to heat and strength in the same relative proportions.

The rate at which the compressive strength develops varies markedly from the rate at which the heat of hydration develops at different ages. In table 7 the average percentages of the 1-year strength and 1-year heat that was developed during the first 7 days and also between 90 days and 1 year are given for the standard portland cements.

TABLE 7.-Comparison of the average heats of hydration and compressive strengths of the standard portland cements developed at various ages

\begin{tabular}{|c|c|c|c|c|c|c|}
\hline \multirow{2}{*}{ Property measured } & \multicolumn{3}{|c|}{$\begin{array}{l}\text { Percentage of 1-year value } \\
\text { developed during first } 7 \text { days }\end{array}$} & \multicolumn{3}{|c|}{$\begin{array}{l}\text { Percentage of } 1 \text {-year value } \\
\text { developed after } 90 \text { days }\end{array}$} \\
\hline & $\begin{array}{l}\text { As } \\
\text { received }\end{array}$ & $\begin{array}{l}3 \% \text { pre- } \\
\text { hydrate }\end{array}$ & $\begin{array}{l}5 \% \text { pre- } \\
\text { hydrate }\end{array}$ & $\begin{array}{l}\text { As } \\
\text { received }\end{array}$ & $\begin{array}{l}3 \% \text { pre- } \\
\text { hydrate }\end{array}$ & $\begin{array}{l}5 \% \text { pre- } \\
\text { hydrate }\end{array}$ \\
\hline Heats of hydration $-\left\{\begin{array}{l}70^{\circ} \mathrm{F} \\
150^{\circ} \mathrm{F}\end{array}\right.$ & $\begin{array}{l}70 \\
86\end{array}$ & $\begin{array}{l}62 \\
82\end{array}$ & $\begin{array}{l}60 \\
73\end{array}$ & $\begin{array}{l}6 \\
4\end{array}$ & $\begin{array}{l}8 \\
4\end{array}$ & $\begin{array}{l}7 \\
5\end{array}$ \\
\hline Compressive strengths $-\left\{\begin{array}{l}70^{\circ} \mathrm{F}_{-} \\
150^{\circ} \mathrm{F}_{\ldots}\end{array}\right.$ & $\begin{array}{l}46 \\
62\end{array}$ & $\begin{array}{l}42 \\
53\end{array}$ & $\begin{array}{l}32 \\
41\end{array}$ & $\begin{array}{r}9 \\
15\end{array}$ & $\begin{array}{l}15 \\
24\end{array}$ & $\begin{array}{l}19 \\
32\end{array}$ \\
\hline
\end{tabular}

As can be seen from table 7 , the heat developed during the first 7 days is proportionately much greater than the strength, but between 90 days and 1 year the heat developed is comparatively small, whereas the strength, particularly of the prehydrated cements, shows considerable gain.

The successive prehydrations of the high-early-strength cements caused successive reductions in the heat evolved at all ages, but in the case of the strengths there were some exceptions to this order.

The two Boulder Dam cements cured at $70^{\circ} \mathrm{F}$ developed, at the age of 7 days, low strengths but the heats developed were proportionately high. At later ages the strengths developed were accompanied by a relatively low evolution of heat. Cured at $150^{\circ} \mathrm{F}$ these cements 
attain strengths comparable to the standard portland cements cured at the same temperature, but evolve less heat.

\section{HEATS AND STRENGTHS FOR COMBINED STORAGE}

All cements and corresponding hydrates, after an initial 6 days' curing at $150^{\circ} \mathrm{F}$, show a substantial gain in both the heats and the strengths. The 1-year results for heats are intermediate between the 1 -year results for continuous 70 and $150^{\circ} \mathrm{F}$ curing, whereas the strengths in general are lower than those obtained from a continuous curing at either temperature. Results obtained from an initial 27 days of curing at $150^{\circ} \mathrm{F}$ show a decrease in the 1-year heats, and, in general, a decrease in the strengths, compared with the 1-year results for an initial 6 days at $150^{\circ} \mathrm{F}$. The 89 -day initial curing at $150^{\circ} \mathrm{F}$ results in lower 1-year heats of hydration, but the strengths remain the same or slightly higher than for the other two combinations of storage.

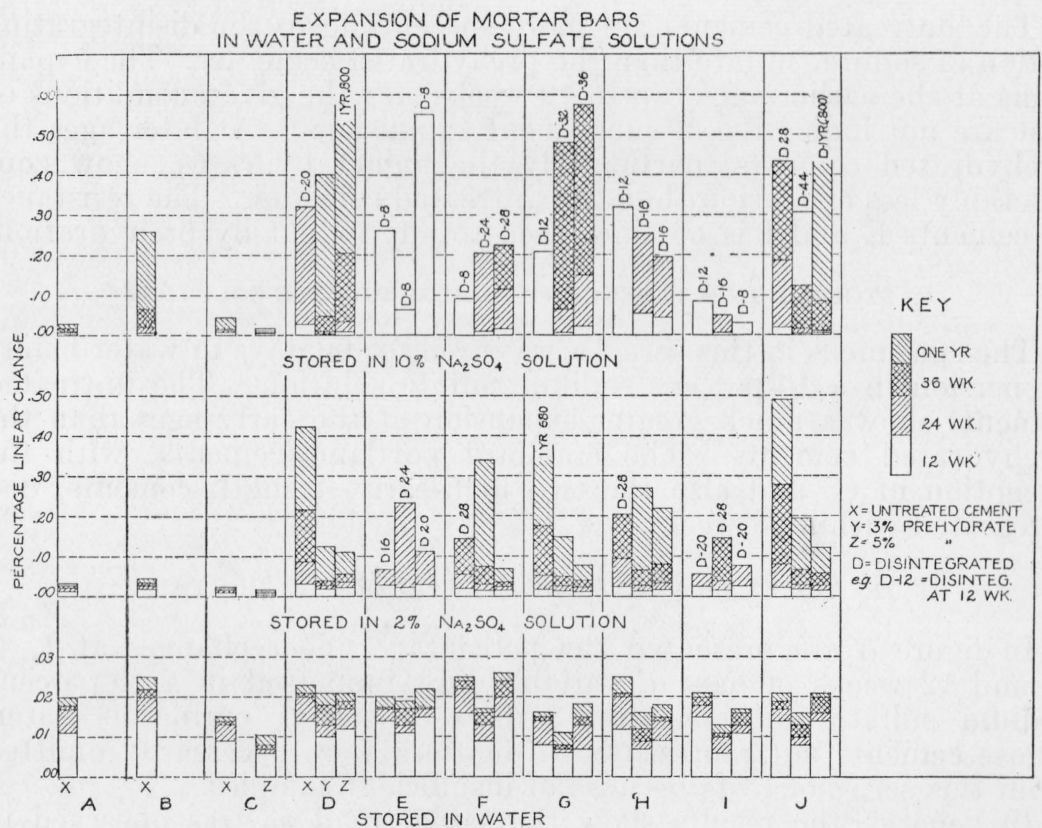

FIGURE 4.-Expansion of mortar bars, made of prehydrated and untreated cements, during immersion in water and sodium sulfate solutions of different concentrations

\section{EXPANSION RESULTS}

\section{CONSTANT MIX, VARIABLE STORAGE}

The expansion results for the 1:2.75 mortar bars are presented graphically in figure 4 . As explained by the key, the respective series of columns represent the linear change of bars in water storage, in 2-percent and in 10-percent solutions of sodium sulfate. 
(a) EXPANSION IN WATER STORAGE

The percentage of linear change of any one of the cements does not show a marked deviation from the average linear change. In general, the coments prehydrated to 3-percent ignition loss show a slightly lower expansion than the untreated cements or the cements of 5-percent ignition loss, the difference being approximately 0.005 percent. A change of this magnitude may be due to a number of factors other than a change of the property of the cement. The 5 -percent prehydrates show approximately the same linear change as the untreated cements.

(b) STORAGE IN A 2-PERCENT SODIUM SULFATE SOLUTION

Cements stored in a 2-percent sodium sulfate solution after the initial 7 days' storage in water show marked differences in expansion. Cements $\mathrm{A}, \mathrm{B}$, and $\mathrm{C}$ are highly resistant to the aggressive action of sodium sulfate, whereas cements $\mathrm{E}$ and I disintegrate at an early age.

The untreated cements are more susceptible to the disintegrating action of sodium sulfate than the prehydrated cements. The expansions at the earlier ages (up to 12 weeks) for the given conditions of test are not indicative of subsequent expansions. At later ages the prehydrated cements, particularly the higher hydrates, show considerably less expansion than the untreated cements. The resistance of cements $\mathrm{E}$ and $\mathrm{I}$ is not increased to any extent by prehydration.

(c) STORAGE IN A 10-PERCENT SODIUM SULFATE SOLUTION

The specimens in this series were cured for 90 days in water before immersion in a 10-percent sodium sulfate solution. The untreated cements show a much greater expansion at the early ages than the prehydrated cements. The standard portland cements, with the exception of C, and also the two high-early-strength cements, disintegrated within 28 weeks.

\section{ACCELERATED SODIUM SULFATE TESTS}

In figure 5 are presented the percentage linear changes at 1,4 , 8 , and 12 weeks of bars of variable mix, immersed in a 10-percent sodium sulfate solution after 3 days of initial curing in water. Those cements not represented in figure 5 were necessarily omitted from this series of tests because of insufficient samples.

In general, the results show the same trend as was observed in the preceding test, namely, a greater resistance to sodium sulfate by the prehydrated cements.

The untreated cements all show the same variation in expansion with a change in mix; that is, the leaner the mix the greater the expansion. This is apparent at all ages of test. The 5-percent prehydrates do not follow such a trend, cements $\mathrm{D}, \mathrm{G}$, and $\mathrm{H}$ showing greater expansions with increasing richness of mix.

\section{SULFATE RESISTANCE ACCORDING TO THE MERRIMAN TEST METHOD}

Pats of neat pastes of the untreated and of the prehydrated cements were tested according to the Merriman method [15]. The best deportment was shown by cement A. This cement showed no effect 
until $1 \frac{1}{2}$ years, then a slight expansion and cracking of the edges was noted. Cements B and $\mathrm{C}$ showed no effects until about 1 year, when slight expansion was noted on the edges. Cement E was the only one to fail before 4 weeks. This same cement when 3percent prehydrated showed no effects until at the age of 23 weeks; when 5-percent prehydrated, disintegration started at 43 weeks. Cement I failed in 8 weeks. Prehydration of this cement affected its resistance only slightly. Cement $\mathrm{F}$ failed in 13 weeks, while both degrees of prehydration extended the failing age to about 40 weeks. Cement $\mathrm{H}$ failed in 15 weeks; 3-percent prehydration extended its life to 67 weeks, and at 75 weeks there is no material effect on the 5-percent prehydrated samples. Of the three other cements, two failed at 40 weeks and the other at 55 weeks. Prehydration to the extent of 3 percent extended the time of failing

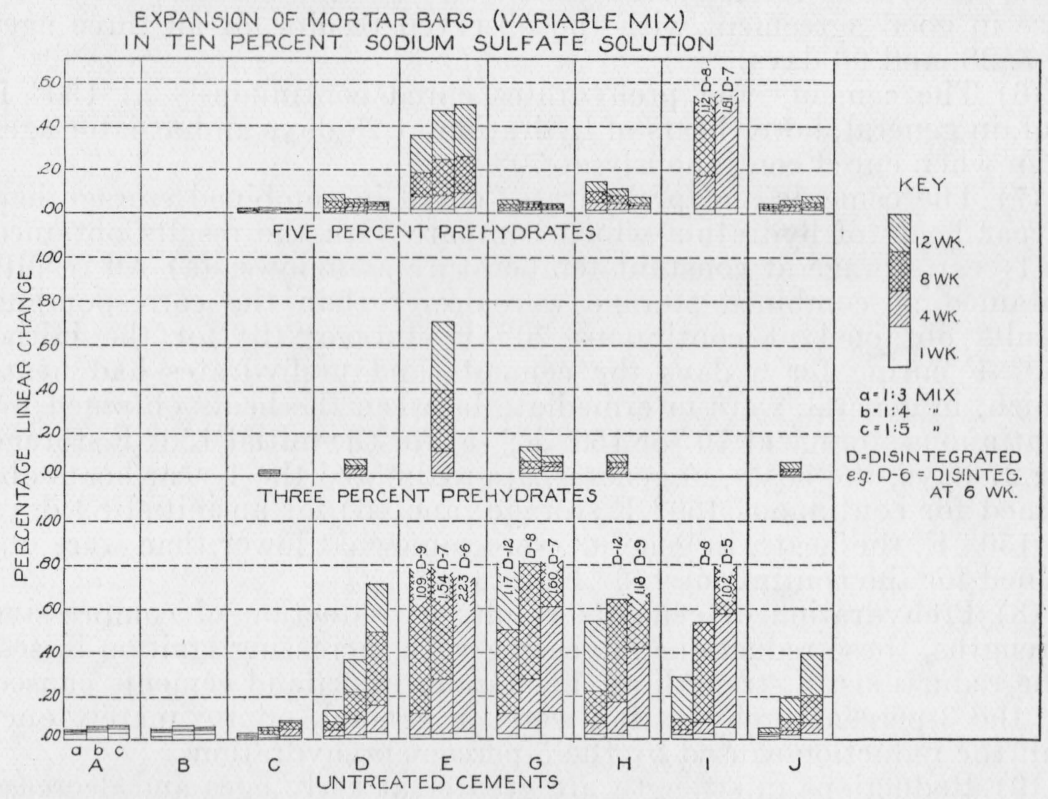

Figure 5.-Expansion of mortar bars (varying mix), made of prehydrated and untreated cements, during immersion in a 10-percent sodium sulfate solution.

from about 2 to 4 months. Five-percent prehydration extended the failing age another 2 to 4 months.

\section{SUMMARY}

(1) An increase in the loss on ignition of cement as a result of steam prehydration is accompanied by a decrease in the heat of hydration. For the standard portland cements this decrease at 7 days averaged approximately 13 and 30 percent, respectively, for the 3 - and 5-percent prehydrates. At 1 year the average percentage decrease was approximately one-half that of the 7-day decrease. For the high-early-strength cements the 3 - and 5-percent prehydration caused an average reduction of 8 and 20 percent, respectively, at 7 days, and 3 and 11 percent, respectively, at 1 year. 
(2) The percentage reduction in heat of hydration caused by the prehydration of the cements was approximately the same for the $150^{\circ} \mathrm{F}$ curing as for the $70^{\circ} \mathrm{F}$ curing.

(3) The calories per gram reduction in heat of hydration for each percent increase in loss on ignition varied widely between individual cements; the average reduction for all the cements at the ages of 7 and 28 days being approximately 6 calories, and the average reduction at 1 year being approximately 4 calories.

(4) The standard portland cements, prehydrated to have a loss on ignition of approximately 5 percent, had heats of hydration at both curing temperatures for the ages of 7 and 28 days that were well within the upper limits named in the specification for the lowheat Boulder Dam cements.

(5) Heats of hydration, calculated from empirical factors, together with corrections for loss on ignition and specific surface, are in no case in good agreement with the observed results for all three ages of 7,28 , and 90 days.

(6) The cements and prehydrates cured continuously at $150^{\circ} \mathrm{F}$ had, in general, lower heats of hydration at 28 days and at later ages than when cured continuously at $70^{\circ} \mathrm{F}$.

(7) The cements and prehydrates cured in combined storage had 1-year heats of hydration which compare with the results obtained at 1-year storage at constant temperature as follows: (a) All results obtained at combined storage were lower than the corresponding results obtained at continuous $70^{\circ} \mathrm{F}$ storage; (b) for the initial $150^{\circ} \mathrm{F}$ curing for 6 days the cements and prehydrates had heats which, in general, were intermediate between the heats obtained for continuous storage at $70^{\circ}$ or $150^{\circ} \mathrm{F}$; (c) for the initial $150^{\circ} \mathrm{F}$ storage for 27 days, the heats, in general, approximated the 1-year heats obtained for continuous $150^{\circ} \mathrm{F}$ storage; and (d) for an initial 89 days at $150^{\circ} \mathrm{F}$, the heats, in general, were somewhat lower than were obtained for the continuous $150^{\circ} \mathrm{F}$ storage.

(8) Prehydration of cements results in reduction of compressive strengths, these reductions increasing with increasing ignition losses. The reductions in strength of the standard portland cements caused by the 3-percent prehydration were, in general, approximately onehalf the reduction caused by the 5-percent prehydration.

(9) Reductions in strength are greater at early ages and decrease with age. The 5-percent prehydration of the standard portland cements caused approximately 40 -percent reduction at 7 days and approximately 20 percent at 1 year. The high-early-strength cements, although less affected by prehydration, follow the same trend.

(10) For continuous storage, the reductions in strength caused by prehydration are, in general, approximately the same for both storage-temperatures, $70^{\circ}$ and $150^{\circ} \mathrm{F}$.

(11) The percentage reductions in compressive strengths per percent increase in ignition losses are, in general, greater at 7 days and then decrease with age. The 3-percent prehydrates of the standard portland cement had, in general, greater proportional reductions in strength than the 5-percent prehydrates.

(12) An initial curing at high temperature (combined storage) results in lower compressive strengths at 1 year than obtained at continuous curing at either $70^{\circ}$ or $150^{\circ} \mathrm{F}$. 
(13) A comparison of the compressive strengths of the Boulder Dam cements with the compressive strengths of the 5-percent prehydrates of the standard portland cement-the group that had heats of hydration that would pass specifications for low heat Boulder Dam cements - shows that for $70^{\circ} \mathrm{F}$ curing the prehydrate strengths averaged 51 and 22 percent greater for 7 and 28 days, and 25 percent less for 90 days and also at 1 year than the Boulder Dam cements. For $150^{\circ} \mathrm{F}$ curing the prehydrate strengths averaged 44, 51, 39, and 24 percent less, respectively, for the ages of $7,28,90$ days, and 1 year than the Boulder Dam cements.

(14) Mortars of prehydrated and untreated cements show approximately the same expansion in water storage.

(15) Prehydration increased the resistance of all the portland cements, with the exception of the two cements with highest tricalcium aluminate content, to the disintegrating action of sodium sulfate. In general, the 5-percent prehydrates were more resistant than the 3 -percent prehydrates.

(16) Mortars of untreated cements show greater expansion for leaner mixes, but no trend is indicated for prehydrated cements.

(17) Tests made according to the Merriman method also showed that prehydration increases the resistance of the cement to the action of sodium sulfate.

\section{CONCLUSION}

The results of this investigation show that prehydration can be successfully used to produce a low-heat, high sulfate-resistant cement without seriously impairing its other properties.

Acknowledgement is made to P. H. Bates, who planned this investigation and directed the work; also to J. Arthur Swenson, who gave assistance throughout in the heat of hydration tests.

\section{REFERENCES}

[1] Unpublished data at the National Bureau of Standards.

[2] Meyers, Rock Products 35, 22 (1932).

[3] Woods, Steinour, and Starke, Ind. Eng. Chem. 24, 1207 (1932).

[4] Davis, Carlson, Troxell, and Kelly, Am. Concrete Inst. 29, 413, (1933); 30, 485 (1934).

[5] Wagner, Proc. Am. Soc. Testing Materials 33, II, 553 (1933).

[6] Bied, Proc. Sixth Congress, Int. Assn. Testing Materials 18, 1 (1912).

[7] Klein and Phillips, Tech. Pap. BS 5 (1914) T43.

[8] Lea and Parker, Building Research Tech. Pap. 16 (1935).

[9] Biddle and Kelly, Proc. Am. Soc. Testing Materials, 33, II, 571 (1933).

[10] Stenzel and Morris, Ind. Eng. Chem., Anal. Ed. 6, 246 (1934).

[11] Bogue, Ind. Eng. Chem., Anal. Ed. 1, 192 (1929).

[12] U. S. Bur. Reclamation Tech. Mem. no. 309. Revised Ed. (Feb. 10, 1933).

[13] Lerch and Bogue, BS J. Research 12, 645 (1934) RP684.

[14] Rapp, J. Research NBS 14, 499 (1935) RP782.

[15] Merriman, U. S. Engineer Specifications for Ft. Peck, Ap. 10 (1934).

Washington, March 25, 1936. 